\title{
Percutaneous Fixation of Comminuted Fractures of the Femur and Tibia
}

\author{
Preliminary Study \\ Wieslaw Pospula Tarek Abu Al Noor Farid Ezzat Farid Abdul Malak \\ Department of Orthopedics, Al Razi Hospital, Kuwait
}

\section{Key Words}

Percutaneous fixation - Minimal access surgery - Early callous formation

\begin{abstract}
Objective: To present initial experience of treating patients with comminuted fractures of the diaphyseal and metaphyseal areas of the femur and tibia. Subjects and Methods: Sixteen patients were involved in the study. All the16 patients (11 males and 5 females, average age 34 years) with closed, comminuted fractures of femur $(n=9)$ and tibia $(n=7)$ were operated on using the principle of minimal access surgery and biological fixation that maximally preserved the soft tissues and fracture hematoma. Results: All the fractures united, operated limbs had good function, and no complications occurred. Conclusion: Our findings indicate that minimal access surgery is a useful fixation method in the treatment of comminuted diaphyseal and metaphyseal fractures of the femur and tibia.
\end{abstract}

Copyright @ 2003 S. Karger AG, Basel

\section{Introduction}

Fixation of a fracture with maximum preservation of surrounding soft tissues is the objective of all systems of internal fixation. In comminuted diaphyseal fractures, however, this principle has been difficult to implement. As a result, anatomical reduction of fragments has been achieved at the expense of soft tissues violation that may result in nonunion, delayed union and/or infection [1-3]. Intramedullary nailing in such cases does not always provide sufficient stability to allow early weight bearing [1]. The biological osteosynthesis method described by various investigators [4-6] has in recent years become the popular technique for the fixation of comminuted diaphyseal fractures. Alignment of fragments without attempting anatomical reduction and the use of percutaneous plate fixation optimizes healing conditions. By minimizing soft tissue disruption and preserving the biological healing potential, fracture healing is improved. In this report, we present our experience with this kind of fixation.

\section{Subjects and Methods}

Between 1999 and 2002 we treated 16 patients (11 males and 5 females, average age 34 years) with closed, comminuted fractures of the femur and tibia using the principle of minimal access surgery and biological fixation that maximally preserved soft tissues and fracture hematoma. The cases involved 9 femoral and 7 tibial fractures. Eight of the femoral fractures were subtrochanteric, while tibial fractures entailed proximal, midshaft and distal fractures. Fifteen patients had high-velocity and 1 low-energy trauma. Ten involved traffic accidents, 5 falls from height, and 1 slipped while walking. The Arbeitsgemeinschaft für Osteosynthesefragen AO/ASIF Classification System was used to classify the fractures [7]. Initial treatment consisted of skeletal traction in the case of femoral fractures and plaster slab for

\begin{tabular}{ll}
\hline KARGER & (c) 2003 S. Karger AG, Basel \\
1011-7571/03/0124-0214\$19.50/0 \\
$\begin{array}{l}\text { Fax +4161306 1234 } \\
\text { E-Mail karger@karger.ch } \\
\text { www.karger.com }\end{array}$ & $\begin{array}{l}\text { Accessible online at: } \\
\text { www.karger.com/mpp }\end{array}$
\end{tabular}

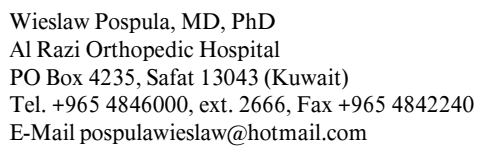

Al Razi Orthopedic Hospital

Tel. +965 4846000, ext. 2666, Fax +965 4842240

E-Mail pospulawieslaw@hotmail.com 
Fig. 1. Postoperative view of the right thigh (case 4).

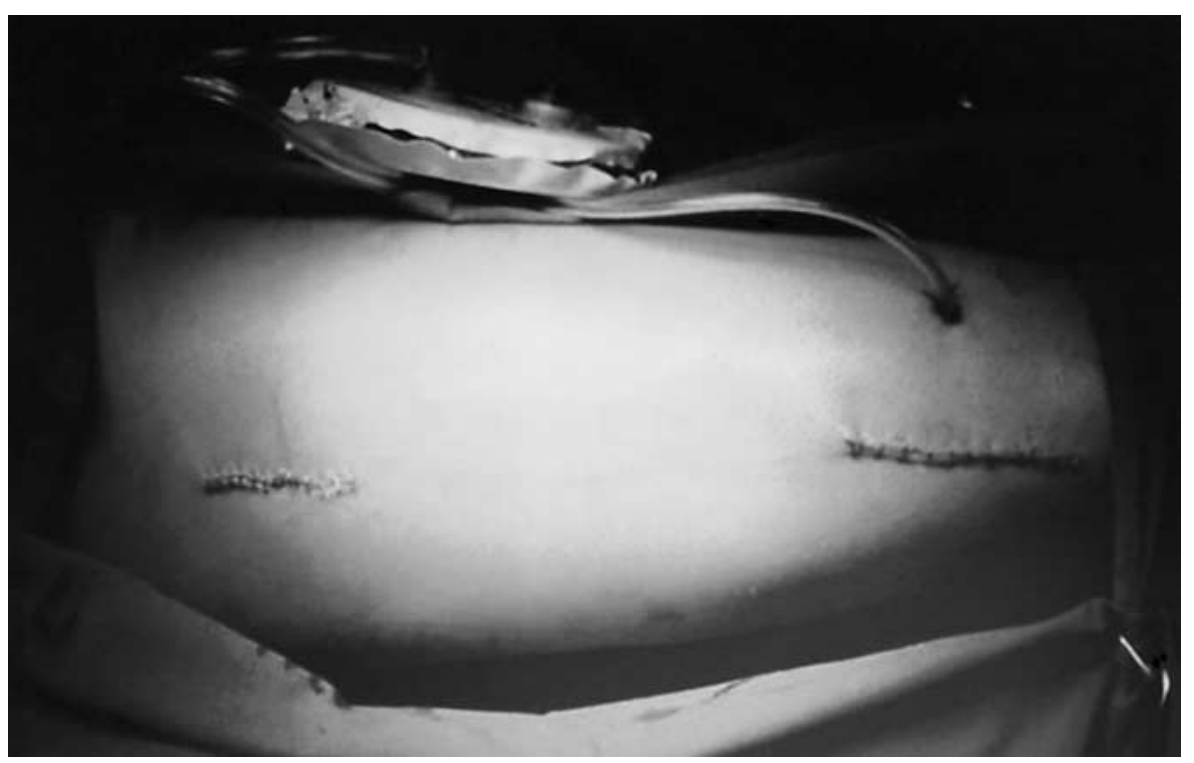

tibial fractures. Delay in surgery ranged from 2 to 10 days. All patients were followed up in the clinic to monitor clinical and radiological progress until union.

\section{Surgical Technique}

A fracture table and traction were used for the femur fractures. In all cases, an image intensifier was used to assess fracture alignment as well as progress of fixation. Fixation was accomplished using standard instrumentation and standard dynamic condylar screw (DCS) implants. After the fracture was manipulated and satisfactory alignment was achieved through mini proximal or distal incisions (fig. 1), DCS implants were placed in the proximal or distal epiphysis. In addition, a long DCS plate was passed under the vastus lateralis muscle and fixed distally and proximally with cortical screws. Intermediate fragments were left undisturbed and no bone grafting was done. Tibial fractures were treated on a regular operating table using a similar technique employing a broad dynamic compression plate (DCP) or low-contact LCDCP. The postoperative regimen involved early mobilization with partial or full weight bearing according to the clinical situation. The average surgical time for femoral and tibial fractures was 100 and $75 \mathrm{~min}$, respectively.

\section{Results}

All the fractures united at an average time of 6.1 months (5-8 months) (table 1). A 70-year-old woman with medical problems and whose surgery was delayed by 10 days was not able to walk 10 weeks after surgery. Her fracture was considered united at 8 months after surgery. There were no local or general complications and all patients except 1 started walking within 1 week after surgery with partial to full weight bearing, depending upon
Table 1. Patient characteristics, fracture and fixation

\begin{tabular}{|c|c|c|c|c|c|c|c|}
\hline Case & $\begin{array}{l}\text { Age } \\
\text { years }\end{array}$ & Sex & Trauma & Fracture & $\begin{array}{l}\text { Loca- } \\
\text { tion }\end{array}$ & $\begin{array}{l}\text { Fixa- } \\
\text { tion }\end{array}$ & Months \\
\hline 1 & 17 & M & RTA & $32 \mathrm{C} 3$ & $\mathrm{Fe}$ & DCS & 6 \\
\hline 2 & 31 & M & RTA & $32 \mathrm{C} 3$ & $\mathrm{Fe}$ & DCS & 7 \\
\hline 3 & 44 & $\mathrm{~F}$ & FFH & $32 \mathrm{C} 3$ & $\mathrm{Fe}$ & DCS & 6 \\
\hline 4 & 22 & M & RTA & $32 \mathrm{C} 3$ & $\mathrm{Fe}$ & DCS & 6 \\
\hline 5 & 24 & M & RTA & $32 \mathrm{C} 3$ & $\mathrm{Fe}$ & DCS & 7 \\
\hline 6 & 70 & $\mathrm{~F}$ & MT & 32B1 & $\mathrm{Fe}$ & DCS & 8 \\
\hline 7 & 33 & M & RTA & $42 \mathrm{~B} 2$ & $\mathrm{~T}$ & DCP & 7 \\
\hline 8 & 19 & M & FFH & $32 \mathrm{C} 2$ & $\mathrm{Fe}$ & DCS & 6 \\
\hline 9 & 39 & M & RTA & $32 \mathrm{C} 3$ & $\mathrm{Fe}$ & DCS & 5 \\
\hline 10 & 41 & M & RTA & $32 \mathrm{C} 3$ & $\mathrm{Fe}$ & DCS & 6 \\
\hline 11 & 31 & $\mathrm{~F}$ & FFH & $41 \mathrm{C} 2$ & $\mathrm{~T}$ & DCP & 6 \\
\hline 12 & 42 & M & RTA & $41 \mathrm{C} 2$ & $\mathrm{~T}$ & LCDCP & 6 \\
\hline 13 & 39 & M & FFH & $43 \mathrm{C} 1$ & $\mathrm{~T}$ & DCP & 5 \\
\hline 14 & 22 & $\mathrm{~F}$ & RTA & $42 \mathrm{Cl}$ & $\mathrm{T}$ & LCDCP & 5 \\
\hline 15 & 34 & $\mathrm{~F}$ & FFH & $42 \mathrm{C} 2$ & $\mathrm{~T}$ & DCP & 6 \\
\hline 16 & 40 & M & RTA & $43 \mathrm{C} 2$ & $\mathrm{~T}$ & DCP & 6 \\
\hline
\end{tabular}

RTA = Road traffic accident; FFH = fall from height $; \mathrm{MT}=$ minimal trau$\mathrm{ma} ; \mathrm{Fe}=$ femur; $\mathrm{T}=$ tibia; $\mathrm{DCP}=$ dynamic compression plate; $\mathrm{LCDCP}=$ low contact dynamic compression plate. the degree of clinical and radiological progress. In all but 1 case, the knee flexion was more than $90^{\circ}$ and there were no cases with significant malalignment. X-rays of 2 cases are presented in figures 2 and 3 , where initial, early postoperative and final $\mathrm{X}$-rays reveal stages of remodeling of the callus. In all the patients, a striking feature was early callus formation. In 4 cases, the evidence of callus formation was found as early as 3 weeks after the surgery. 
Fig. 2. a Pre- and postoperative views of a fracture of the femur (case 1). b Final X-ray of united fracture of femur with remodeling at 6 months (case 1).
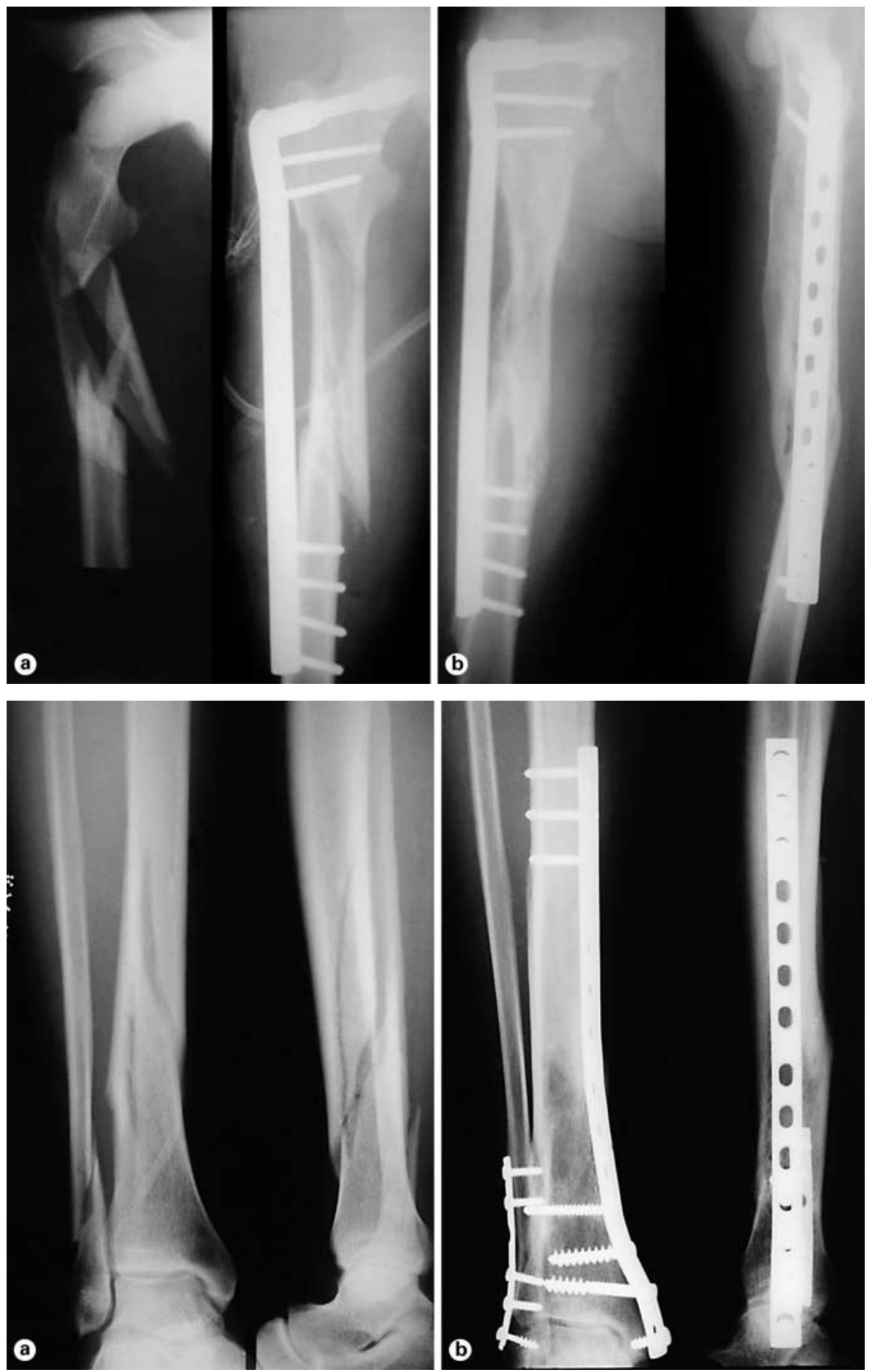

Fig. 3. a Pre- and postoperative views of fracture of the tibia (case 4). b Final X-ray of united fracture of tibia with remodeling at 6 months (case 4).

cient strength to allow early mobilization, and at the same time, maintain good vascularity of the fragments, leaving the soft tissues and fracture hematoma undisturbed to

Fixation of comminuted fractures of diaphyseal and metaphyseal areas presents a challenging problem for the orthopedic surgeon. The fracture must be fixed with suffioptimize bone healing potential. In the past, meticulous anatomical reduction and bone grafting, in addition to 
plating, was recommended, frequently resulting in extensive devascularization of fragments and high risk of infection and nonunion $[2,3]$. Fixation with interlocking nails is an alternative, but is not always appropriate depending on the fracture type and location.

The idea of biological fixation, evolving gradually from the early 1980s, has become the preferred method of treatment for comminuted diaphyseal and metaphyseal fractures due to the introduction of new implants and instruments $[2,4]$. In view of these developments, anatomical reduction and rigid internal fixation is no longer a goal of treatment in comminuted diaphyseal fractures $[1,8]$. In this study, despite nonanatomical reduction and poor contact of fragments, good callus formation and remodeling occurred. Bone grafting was not required in any of our cases in spite of extensive comminution.

The surgical time, significantly longer than in conventional open surgery, probably due to iatrogenic and instrument-related factors, did not result in any immediate or late complications as the surgical trauma was minimal.

The coupling of the dynamic compression screw with the plate was the most difficult step in femoral fractures with relatively small incisions. The use of a long plate was based on results of experimental studies that demonstrated significantly higher axial and torsional stiffness of a long plate-bone construct over a shorter plate [1,9]. Rozbruch et al. [1], using regression analysis, have shown that using a long plate as well as limiting the number of screws to no more than three on each side of the plate is a good predictor of success. We did not observe implant failure in any of our cases in spite of early mobilization and weight bearing. Bone grafting, which was considered necessary in the past for the surgical treatment of comminuted fractures, is no longer necessary as shown in this study and that of Rozbruch et al.

\section{Conclusion}

Minimal access surgery in the treatment of comminuted fractures of the diaphyseal and metaphyseal areas of the femur and tibia is a useful method of surgical fixation. No complication occurred in our study and all fractures united.

\section{References}

1 Rozbruch SR, Muller U, Gautier E, Ganz R: The evolution of femoral shaft plating technique. Clin Orthop 1998;354:195-208.

2 Leunig M, Hertel R, Siebenrock KA, Ballmer FT, Mast JW, Ganz R: The evolution of indirect reduction techniques for the treatment of fractures. Clin Orthop 2000;375:7-14.

3 Chrisovitsinos JP, Xenakis T, Papakostides $\mathrm{KG}$, Skaltoyannis N: Bridge plating osteosynthesis of 20 comminuted fractures of the femur. Acta Orthop Scand 1997;68(suppl 275):72-76.
4 Miclau T, Martin RE: The evolution of modern plate osteosynthesis. Injury 1997;28(suppl)A3A6.

5 Schatzker J: Osteosynthesis in trauma. Int Orthop 1996;20:244-252.

6 Lambotte A: The classic contribution to conservative surgery of the injured hand. Clin Orthop 1987;214:4-6.

7 Mueller ME: Comprehensive Classification of Fractures. Davos, AO/ASIF Documentation Center, 1996.
8 Karnezis IA: Biomechanical considerations in 'biological' femoral osteosynthesis: An experimental study of the 'bridging' and 'wave' plating techniques. Arch Orthop Trauma Surg 2000;120:272-275.

9 Kaznezis IA, Miles AW, Cunningham JL, Learmonth ID: Biological internal fixation of long bone fractures: A biomechanical study of a noncontact plate system. Injury 1998;29:689_ 695. 